Animal Health Research Institute

Assiut Regional Laboratory

\title{
STUDIES ON SALMONELLA AND E.COLI IN SOME MEAT PRODUCTS (BEEF BURGERS AND LUNCHEON) SOLD IN ASSIUT CITY.
}

(With 3 Tables)

By

\author{
H.H. ESSA; A.M. MANAA; N.H. MAKAR \\ and S.M. SAYED.
}

(Received at 4/3/2009)

دراسات على ميكروبى السلامونيلا والايثيثيرشيا كولاى في بعض منتجات اللحوم

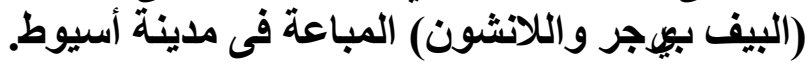

حدلى حسين عيسى ، أحدا مددوح مناع ، نبيل حبيب مقار، سبي محد سبيل .

نظر الأهمية و خطورة بعض الميكروبات على صحة الإنسان وكيفية وصول هذه الميكروبات

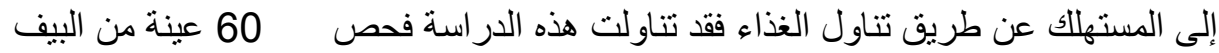

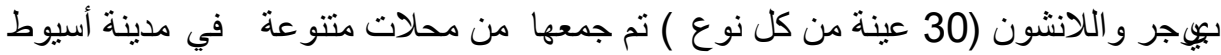

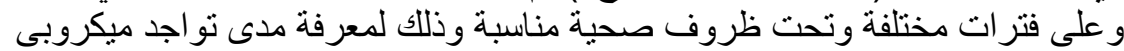

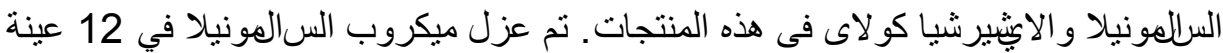

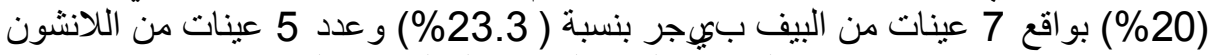

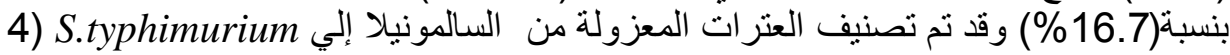

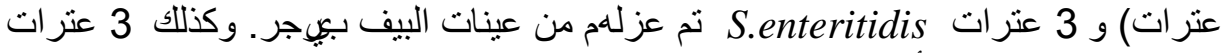
S.paratyphi-B

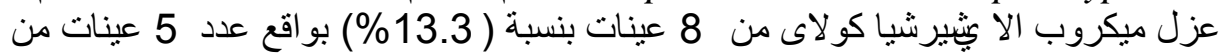

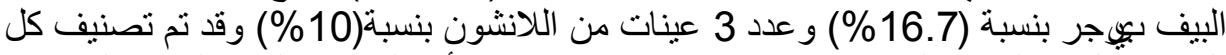

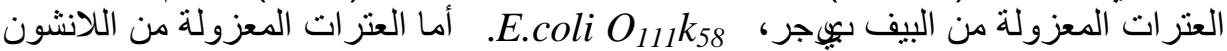

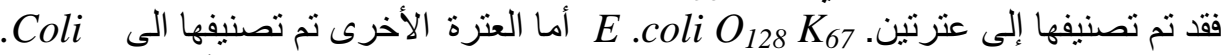
E O O $O_{126} K_{7}$ العينات حتى لا تشكل خطر اً على صحة المستهلك.

\section{SUMMARY}

Recovery of Salmonella and Escherichia coli from a total number of 60 random samples of different types of packed meat products was evaluated. The collected samples were 30 from each beef burger and luncheon samples. Out of the analyzed 60 samples. Salmonella could be 
detected only in 12 samples (20\%), where 7 (23.3\%) isolates were recovered from beef burger, and another 5 (16.7\%) isolates from luncheon samples. The isolated Salmonella serotypes were 4 strains of Salmonella typhimurium and 3 strains of Salmonella enteritidis which were detected in the examined beef burger samples, while 3 Salmonella paratyphi- $B$ and 2 Salmonella newport strains were recovered from luncheon samples. Regarding E.coli, they were detected in only 8 (13.3\%) samples; 5(16.7\%) strains from beef burger and 3(10\%) from luncheon. The isolated E.coli strains from beef burger were identified serologically into 5 strains E.coli $O_{111} K_{58}$, while the strains isolated from luncheon were two strains E.coli $O_{128} K_{67}$ and only one strain E.coli $O_{126}$ $K_{7}$. Source of contamination, precautions during preparation and manufacturing of such meat products, as well as the public health hazards of the presence of Salmonella and E.coli in meat products were discussed.

Key words: Salmonella, E. Coli, beef burgers, luncheon

\section{INTRODUCTION}

Meat and meat products are considered as a major vehicle of most reported out breaks of food borne diseases. Epidemiologic data have identified improperly handled meat products as important vehicles for infection (ICMSF, 1980).

Changes in the behavior of food consumption by humans, the processing and distribution of food, globalization as well as adaptations of microorganisms, themselves affect the development of new pathogens and the increase in the occurrence of bacteria admitted to be agents of diseases transmitted by food (Jure, et al. 2006).

Food borne salmonellosis remains a major public health problem. Early detection of salmonella is important for the limitation of outbreaks (Kawaski, et al., 2000). Food borne diseases caused by non-typhoid Salmonella represent an important public health problem worldwide so nearly104 million cases of salmonellosis occur each year in the United States (Angulo, et al., 2000). Intestinal salmonellosis typically resolves in five to seven days and does not require treatment with antibiotics. However, bacteraemia occur in 3 to $10 \%$ of reported, cultured confirmed cases and is particularly common among patient at the extremes of age and those who are immunocompromised. When infection spreads beyond the intestinal tract, appropriate antimicrobial therapy (e.g., ciprofloxacin in adult and ceftriaxone in children) can be lifesaving 
(Glynn et al., 1998; Hohamanon, 2001). Non -typhoidal salmonellosis an important enteric infection in humans, particularly in the neonates and younger children (Gupta and Vermo, 1993). Most Salmonella infections in humans result from the ingestion of contaminated poultry, beef, pork, eggs and milk (Gomez et al., 1997). Most infections with antimicrobial resistant Salmonella is acquired eating contaminated food of animal origin (Angulo et al., 2000). Salmonella do not release toxins into food in which they multiply rather, the ingested cells multiply in the small intestine of the victim, causing illness. This illness is characterized by diarrhoea, vomition and abdominal pain after an incubation period of 24-36 hours (Wyatl, 1992).

Many people enjoy beef burgers, luncheon and other meat products, especially during the summer months. However, raw and improperly handled luncheon and beef burgers can harbour harmful bacteria including Escherichia coil. The bacteria constituting the species $\mathrm{E}$.coli are bacteria that normally live in the intestines of human and animals. Although most strains are harmless, several are known to produce toxins that can cause diarrhea. The pathogenic groups includes enterotoxigenic E. coli (ETEC), enteropathogenic E. coli (EPEC), enterohemorrhagic E. coli (EHEC), enteroinvasive E. coli (EIEC), enteroaggregative E. coli (EAEC), diffusely adherent E. coli (DAEC). Only the first 4 groups have been implicated in food or water borne illness (Levine, 1987; Nataro and Kaper, 1998). Many researches concluded the enteropathogenic $E$. coli isolated from different meat products was incriminated in different diarrhea and gastrointestinal out breaks in adult human (Marier et al., 1973; Edelman and Levine, 1983).

This study is planned to investigate the presence of Salmonella and other pathogenic E. coli serotypes among some selected meat products. The public health significant of the isolated pathogens is discussed.

\section{MATERIALS and METHODS}

\section{I - Collection of samples:}

A total number of 60 random samples of various types of packed meat products were collected from different shops and supermarkets at Assiut city. The collected samples included 30 from each beef burger and Luncheon.

The samples were obtained in their intact original package and transferred as quickly as possible to the laboratory for bacteriological 
examination. Samples under investigation were prepared to be examined for the presence of Salmonella and E. coli.

\section{II - Isolation and identification of Salmonella organisms:}

Twenty grams of each sample were inoculated into $100 \mathrm{ml}$ of peptone water and incubated at $37^{\circ} \mathrm{C}$ for $24 \mathrm{~h}$. Then $10 \mathrm{ml}$ of the incubated peptone water were inoculated into $100 \mathrm{ml}$ of selenite $\mathrm{F}$. broth. After incubation at $37^{\circ} \mathrm{C}$ for $18-24$ h., a loopful of the incubated enrichment broth was streaked onto MacConkey's, Brilliant green and S.S agar media. Inoculated plates were incubated at $37^{\circ} \mathrm{C}$ for $24 \mathrm{~h}$. Suspected colonies presumed to be Salmonella (non lactose fermenters) were further identified morphologically and biochemically according to Koneman et al. (1994) and Quinn et al. (1994).

Isolates that produced biochemical reactions simulation Salmonella were subjected to serological identification as described by Edward and Ewing (1972) and the instruction of the technical information of the manufacture laboratory (Anon, 1975). The final decision of typing was made according to Kauffimann white scheme (kauffimann, 1972).

\section{III - Isolation and identification of E.coli}

The technique was carried out according to FAO (1979).

Presumptive test: one $\mathrm{ml}$ from the previously prepared dilutions was inoculated into lauryl sulphate tryptose broth fermentation tubes with inverted Durham's tubes.

The tubes were incubated at $35-37{ }^{\circ} \mathrm{C}$ for 24 and $48 \mathrm{~h}$. Tubes showing gas production were recorded as positive.

Confirmation test: A loopful from each positive tube in the presumptive test was transferred separately into each of three $\mathrm{E} \mathrm{C}$ broth tubes with inverted Durham's tubes. The tubes were incubated at $45^{\circ} \mathrm{C}$ for $48 \mathrm{~h}$. Tubes showing gas production were considered positive. From each gas positive tube of E C broth, a loopful was streaked on Levine's Eosin Methylene Blue (EMB) agar plates. The plates were incubated at $35-37^{\circ} \mathrm{C}$ for $24 \mathrm{~h}$. Isolated typical colonies or colonies most likely to be E. coli were subjected to further identification by biochemical tests including indole, Methyl red, Vogues proskauer and Citrate (IMVIC reaction). The most Probable Number (MPN) of E. coli per gram of the examined samples was determined (A.O.A.C., 1984).

\section{RESULTS}


Table 1: Incidence of Salmonella and E. coli in examined meat products samples.

\begin{tabular}{|c|c|c|c|c|c|}
\hline \multirow{2}{*}{$\begin{array}{c}\text { Types of } \\
\text { examined samples }\end{array}$} & \multirow{2}{*}{$\begin{array}{c}\text { Number of } \\
\text { examined samples }\end{array}$} & \multicolumn{4}{|c|}{ Positive samples. } \\
\cline { 3 - 6 } & & $+\mathrm{Ve}$ & $\%$ & $+\mathrm{Ve}$ & $\%$ \\
\cline { 3 - 6 } & 30 & 7 & 23.3 & 5 & 16.7 \\
\hline Beef burger & 30 & 5 & 16.7 & 3 & 10 \\
\hline Luncheon & 60 & 12 & 20 & 8 & 13.3 \\
\hline Total & & \multicolumn{4}{|c}{ E.coli } \\
\hline
\end{tabular}

Table 2: Salmonella serotypes isolated from the examined samples.

\begin{tabular}{|c|c|c|c|c|}
\hline \multirow{2}{*}{ Serotypes } & \multicolumn{2}{|c|}{ Frequency of isolation } & \multirow{2}{*}{ Total } & $\%$ \\
\cline { 2 - 3 } & beef burger & Luncheon & & \\
\hline S.typhimurium & 4 & - & 12 & 20 \\
S.enteritidis & 3 & - & & \\
S.paratyphi-B & - & 3 & & \\
S.new port & - & 2 & & \\
\hline
\end{tabular}

Table 3: E. coli serotypes isolated from the examined samples.

\begin{tabular}{|l|c|c|c|c|}
\hline \multirow{2}{*}{ Serotypes } & \multicolumn{2}{|c|}{ Frequency of isolation } & \multirow{2}{*}{ Total } & $\%$ \\
\cline { 2 - 3 } & Beef burger & Luncheon & & \\
\hline E. coli $O_{111} K_{58}$ & 5 & - & & \\
E. coli $O_{128} K_{67}$ & - & 2 & & \\
E. coli $O_{126} K_{7}$ & - & 1 & & 13.3 \\
\hline
\end{tabular}

\section{DISCUSSION}


Meat and meat product play a role in most reported outbreaks of food borne diseases. Certain pathogenic microorganism in or on food of animal origin still constitute a particular hygienic risk.

Salmonellae are important pathogens in both animal and man. They are ubiquitous microorganisms that have been found in most of the animal species in most of the geographic areas of the world. Salmonellosis today is one of the most important foods borne disease which caused a significant public health problem. Foods of animal origin particularly meat and meat products are still the major source of human salmonellosis.

It is evident from the present investigation that the incidence of Salmonella in the examined beef burger and luncheon was 7(23.3\%) and $5(16.7 \%)$, respectively (Table, 1). Table (2) shows that the Salmonella serotypes were identified from beef burger samples. Four strains of S.typhimurium and three strains of $S$. enteritidis were detected, while three strains of $S$. paratyphi- $B$ and two strains of S.newport were recovered from the examined luncheon samples.

Many investigators isolated Salmonella from the examined beef burger. The obtained results, in the present study, were higher than the results recorded by Darwish et al. (1986) (5\%); Ahmed and Abdel- aziz (1988) (6\%); El-Mossalami. et al. (1989) (6\%); Fathi and Thabet (2001) (16.67\%) and Essa and Makar (2003) (6.6\%). Whereas, other workers could detect the organism in beef burger samples similar to that obtained in the present work; as Karim (1976); Ibrahim (1981); Tolba (1986); Abdel- Aziz (1987) and Khalafalla (1988).

On the other hand Salmonella organisms detected in the examined luncheon were higher than that detected by Essa et al., 2004 (6.6\%). Concerning Salmonella serotypes, S. typhimurium were the commonest strain isolated from similar meat products by most investigators. Darwish et al. (1986) and Fathi and Thabet (2001) succeeded to isolate $S$. typhimurium and $S$. paratyphi from the examined beef burger. $S$. typhimurum and $S$. typhi were recovered also from luncheon by Essa et al. (2004).

Meat products may be contaminated with E. coli from food handlers, food utensils, air, soil and water under incomplete hygienic measure during manufacturing, packing and marketing of these products (Frazier and Westhoff, 1978). In the present study the incidence of $E$. coli in the examined beef burger and Luncheon samples was $5(16.7 \%)$ and $3(10 \%)$, respectively (Table 1$)$. From the results achieved in Table (3) it was found that out of $8(13.3 \%)$ isolates of E.coli 
recovered from the examined beef burger and luncheon samples were serologically typed as Enteropathogenic E. coli (EPEC). E. coli serotypes recorded and identified from beef burger samples were 5 strains of E. coli $O_{111} K_{58}$. While 2 strains of E.coli $O_{128} K_{67}$ and one strain of $E$. coli $O_{126} K_{7}$ were recovered from the examined luncheon samples.

The results in Table (1), it reveals that E. coli was isolated from $16.7 \%$ and $10 \%$ of the examined beef burger and luncheon, respectively. The present study indicates that the incidence of $E$. coli isolates was particularly low in beef burger which seem to be lower than the results reported by Duitschaever et al. (1977) (27.72\%); Darwish et al. (1986) (30\%); Tolba (1986) (25\%) and Essa and Marker (2003) $(23.33 \%)$, but the results detected in the same study was higher than the result recorded by Darwish et al. (1991)(12\%) in the beef burger examined samples. On the other hand, very high existence of $E$. coli in beef burger has previously been reported by Abdel- Aziz (1987) (70\%).

Many investigators concluded that EPEC isolated from different meat products was incriminated in different infantile diarrhea and gastrointestinal outbreaks in adult human (Dupont et al., 1971; Marier et al., 1973; Edelman and Levine, 1983).

In conclusion, many workers, have stated that $E$. coli as one of predominant Enterbacteriaceae should be taken into account when considering the sanitary standards and hygiene of food handling particularly minced meat, beef burger, luncheon and other local manufactured products either frozen or fresh (Stiles and Lai-King, 1981; Gobran, 1985; Niazi and Refai, 1988).

\section{ACKNOWLEDGMENT}

I wish to express my sincere thanks to Prof. Dr. A. El-Tamawy Professor of Bacteriology, Faculty of Medicine, Assiut University, for his help in Salmonella and E. coli stereotyping.

\section{REFERENCES}

Abdel-Aziz, A.T. (1987): Microbiological load of some meat products as influenced by the hygienic status of the producing plant. M.V. SC., Thesis, Fac. Vet. Med., Cairo Univ.

Ahmed, S. and Abdel-aziz, M. (1988): Salmonellae in locally manufactured meat products. M.V SC., Thesis, Fac. Vet. Med., Cairo Univ. 
Angulo, F.J.; Johnson, K.R.; Tawxw, R.V. and Cohen, M.L. (2000): Origin and consequences of antimicrobial resistant nontyphoidal Salmonella: Implication for the use of fluoroquinolones in food animals. Microb Drug. Resist. 6: 7783.

Anon, (1975): Serological identification of Salmonella. Difco Laboratories, Deteroit, Michigan, U. S. A., 0168.

A.O.A.C. (Association of Official Analytical Chemistis) (1984): Bacteriological analytical Manual $6^{\text {th }}$ Edition FDA, Arlinglon, V A, U.S.A.

Darwish, A.; Hamdy, M. and Nouman, T.M. (1986): Quality evaluation of market meat pastes .Vet. Med. J., 34, 1:37-48.

Darwish, A.M.; Niazi, Z.M. and Zaki, E.M. (1991): Escherichia coli in meat products. Vet. Med. J., Giza, 39, 3: 841-851.

Duistchaever, C.L.; Bullock, D.H. and Arnott, D.R. (1977): Bacteriological evaluation of retial ground beef frozen beef patties and cooked hamburgers. J. Food Prot., 40, 6: 378-381.

Dupont, H.L; Formal , S.B.; Hornick, B.B.; Snyder, M.J.; Libonati, J.P., Sheehan, D.G.; Lobrec, E.H. and Kalas, J.P. (1971):

Pathogensis of E coli diarrhaea. N. Engl. J. Med., 285: 1-9.

Edelman, T. and Levine, M.M. (1983): Summary of a workshop on Entero pathogenic Escherichia coli. J. Infect. Dis., 147: 11081118 .

Edwards, R.P. and Ewing, W.H. (1972): Identification of Enterobacteriaceae. Minnoapolis, Burgess, Publ. Co. Atlanta, U.S.A.

El-Mossalmi, E.E.; Safwat, A.A.S.; Abdel-Rahim, L. and El-Sawah, H. (1989): Salmonella in locally produced meat products. J. Egypt Vet. Med. Ass., 49, 1-2: 99-108.

Essa, H.H. and Makar, N.H (2003): Bacteriological quality of beef burgers in Assiut City. Assiut. Vet. Med. J. 49, 99: 81- 88.

Essa, H.H.; Makar, N.H. and Sohair, Z.H. (2004): Bacteriological evaluation of chicken luncheon in Assiut City. Assiut. Vet. Med. J. 50, 102: 64-71.

FAO (1979): Food Agriculture Organization of the United Nations, Rome, Manuals of Food Quality Control, 4. Microbiological analysis, via delle terme dicaracalla, 00100 Rome, Italy.

Fathi, M. Sh. and Thabet, A. El-R. (2001): Incidence of Salmonella and E. coli in packed meat products sold in Assiut City. Assiut Vet. Med. J. 46, 91:187-198. 
Frazier, W.C. and Westhoff, D.C. (1978): Food Microbiology $3^{\text {rd }}$ Ed. Tata ACG row Hill Publ, Comp. Lted, Newdelhi.

Glynn, M.K.; Bopp, C.; Dewitt, W.; Dobney, P.; Mokhtar, M. and Angulo, F.J. (1998): Emergence of multidrug. resistant Salmonella enterica serotype typhimurium of 104 infections in the United States, N Eng. J. Med., 338:1333-1338.

Gobran, R.A. (1985): Enterobacteriaceae in meat products in Upper Egypt. M.V Sc. Thesis, Fac. Vet. Med., Assiut Univ.

Gomez, T.H.; Motarjemi, Y; Miyagawa, S.; Kuferstin, K.F. and Stohr, K. (1997): Food borne salmonelosis. World Health State Q., 50: 81-89.

Gupta, B.R. and Vermo, C.J. (1993): Monograph on animal salmonellosis. Lzatnagar: National Salmonella Center (Veterinary), Div. Bacterial, Mycol., IVRI: 9-11.

Hohamanon, E.L. (2001): Non-typhoidal Salmonellosis. Clin Infect Dis., 32: 263-269.

Ibrahim, A.M. (1981): Sanitary condition of locally produced hamburger, M.V. Sc. Thesis, Cairo University.

ICMSF (1980): Microbial Ecology of Food, Vol. 1, Univ. of Toronto Press Toronto. Canada.

Jure, A.M.; Aulet De Saab, O.; Suarez, A. and De Castillo, C.M. (2006): Assessment of survival and production of Shiga toxins by enterohemorrhagic E. coli in stored hamburgers. J., of Food Technology, 4(3): 194-199.

Karim, G. (1976): Bacteriological quality of raw and cooked hamburgers at the retail level in Theran. J. Food Prot. 40: 560.

Kawaski, S.; Kimura, B. and Fuji, T. (2000): Comparison of taq man ${ }^{\mathrm{TM}}$ Salmonella amplification detection kit with standard culture procedure for detection of Salmonella In meat samples. Pakistan J. of Biological Sci. 10(1): 122-126.

Khalafalla, F.A. (1988): Sanitary status of meat, meat products and fish in Beni Suef Governorate. Ph. D. Thesis, Vet. Met., Cairo Univ.

Konemon, E.W.; Allen, S.D.; Janda, W.M.; Schrecken-Berge, P.C. and Winn, W.C. (1994): Introduction to Diagnostic Microbiology $4^{\text {th }}$ ed. J. B. Lippincott Company., P. 41.

Kouffimann, F. (1972): Serological diagnosis of Samonella species. Kouffinann-White Scheme. Munksgaard. Copenhagen.

Levine, M.M. (1987): Escherichia coli that cause diarrhea enterozoxigenic, enteroinvasive, enterohemorrhagic, and enteroadherent. J. Infect. Dis., 155: 377-389. 
Marier, R.; Wells, J.; Swanson, R.; Collahn, S. and Mehlaman, I. (1973): An outbreak of E. coli food borne disease traced to imported French cheese. Lancet, 2:1376.

Nataro, J.P. and Kaper, J.B. (1998): Diarrheagnic Escherichia coli. Clin. Microbial. Rew., 11:132-201

Niazi, M.Z. and Refai, M. (1988): Isolation of enteropathogenic and enterotoxigenic Escheriachia coli from meat and cheese. Vet. Med. J., 36, 1:121-134.

Quinn, P.J;.Carter, M.E.; Markery, B.K. and Careter, G.R. (1994): Clinical Vet. Microbiology. Year book Wolfe Publishing Europe Limited, P. 209-236.

Stiles, M.E. and Lai-King, Ng, (1981): Enterobacteriaceae associated with meat and meat handling. Appl. and Environmental Microbiology. 41, 4: 867-872.

Tolba, K.S. (1986): Antibiotic resistant microorganisms in some meat products. M. V. Sc., Thesis, Fac. Vet., Med., Cairo University.

Wyatl, G.M. (1992): Immuno Assays for Food Poisoning Bacterial and Bacterial Toxins. Chapman and Hall. $1^{\text {st }}$ Ed, Pp. 5-15. 